\title{
TEMPERATURE EFFECTS ON THE GERMINATION OF HERBAGE LEGUMES IN NEW ZEALAND
}

J.G. Hampton', J.F.L. Charlton ${ }^{2}$, D.D. Bell' and D.J. Scott'

'Official Seed Testing Station, MAF, Palmerston North

${ }^{2}$ Grasslands Division, DSIR, Palmerston North

\section{Abstract}

Percentage germination and germination rate (days to $75 \%$ germination) of 14 herbage cultivars from 5 legume species wereassessed at constant temperatures of $5,10,15,20^{\circ} \mathrm{C}$ and a fluctuating temperature of $5 / 10^{\circ} \mathrm{C}$. The percentage germination of white clover, red clover and lucerne was not affected by temperature. Germination of Woogenellup subterranean clover was reduced at $5^{\circ} \mathrm{C}$, the germination of Mt Barker subterranean clover was reduced at $20^{\circ} \mathrm{C}$, and the germination of Maku lotus was reduced at $5^{\circ} \mathrm{C}$ and $5110^{\circ} \mathrm{C}$.

Germination rates for all species slowed as temperatures moved away from the optimum, as did the number of days to the start of growth. The species order for germination rate was lucerne, white clover $>$ subterranean clover $>$ red clover $>$ lotus at $10^{\prime}$ and $5 / 10^{\circ} \mathrm{C}$, and subterranean clover (except cv. Woogenellup), whiteclover, lucerne $>$ red clover $>$ lotus at $5^{\circ} \mathrm{C}$ Germination rates differed between subterranean clover cultivars, and also between individual seedlots of subterranean clover, red and white clover and lotus, particularly at $5^{\circ} \mathrm{C}$. The implications of these results for pasture establishment are discussed.

Keywords: germination rate, pasture establishment

\section{INTRODUCTION}

Lancashire (1985) estimated that $3.4 \%$ of New Zealand's pastures are renovated annually, and that during this process 1,300t of white clover and 250t of red clover seed are sown. The use of high quality seed is a basic requirement for successful pasture establishment, yet Lancashire (1985) reported that uncertified mixtures formed a high percentage of clover sowings in some districts.

Successful establishment has a major effect on the subsequent performance of a pasture species. Legume establishment in lowland pastures following cultivation is high, although overdrilling results have been variable. However, in unploughable hill country, establishment varies considerably and is usually poor. The effects of time of sowing (Suckling 1959), aspect (Charlton 1977), ground cover (Cullen 1971), pests (Charlton 1982), moisture (Smith \& Stiefel 1978) and temperature (Musgrave 1982) on legume establishment have all been investigated.

Charlton et al. (1986) showed that as temperatures moved away from the species optimum, the germination rates of New Zealand herbage grasses decreased, and considered that this factor may seriously affect the success of autumn pasture establishment. Further work reported here examined the effects of temperature on the germination and germination rate of New Zealand herbage legume cultivars and three Australian subterranean clover cultivars used in New Zealand pastures.

\section{MATERIALS AND METHODS}

The percentage germination (ISTA 1985) of 14 cultivars (listed in Table 2) from 5 herbage legume species (Trifolium repens L., T. pratense L., J. subterraneum L., Medicago sativa L., Lotus uliginosus Schk.) was determined at constant temperatures of $5^{\circ} \mathrm{C}, 10^{\circ} \mathrm{C}, 15^{\circ} \mathrm{C}, 20^{\circ} \mathrm{C}$, a fluctuating temperature of $5^{\circ} / 10^{\circ} \mathrm{C}(16 \mathrm{~h} / 8 \mathrm{~h}$ per day) and standard germination temperatures for each species (Table 1). Prior to germination, seedlots which had a high percentage of hard seed were scarified by abrading them in a laboratory scarifying chamber using compressed air at $0.844 \mathrm{~kg}$ 
Table 1: Total number of herbage legume seedlots tested and percentage of seedlots with germination $90 \%$ or greater $1983-85$

\begin{tabular}{|c|c|c|c|c|c|c|c|c|c|c|}
\hline & \multirow[b]{2}{*}{ Cultivars } & \multirow{2}{*}{$\begin{array}{l}\text { Standard } \\
\text { germination } \\
\text { emperature } \\
{ }^{\circ} \mathrm{C}\end{array}$} & \multicolumn{2}{|c|}{1983} & \multicolumn{2}{|c|}{1984} & \multicolumn{2}{|c|}{1985} & \multicolumn{2}{|c|}{3 year average } \\
\hline & & & $\begin{array}{c}\text { Total } \\
\text { seedlots }\end{array}$ & $\begin{array}{l}>90 \\
\%\end{array}$ & $\begin{array}{c}\text { Total } \\
\text { seediots }\end{array}$ & $\begin{array}{c}>90 \\
\%\end{array}$ & $\begin{array}{c}\text { Total } \\
\text { seedlots }\end{array}$ & $\begin{array}{l}>90 \\
\%\end{array}$ & $>\underset{\%}{>90}$ & $\begin{array}{c}>80 \\
\%\end{array}$ \\
\hline White & Huia & 20 & 1511 & 72 & 1235 & 72 & 1037 & 76 & 73 & 96 \\
\hline \multirow[t]{2}{*}{ Clover } & Pitau & 20 & 133 & 59 & 80 & 70 & 88 & 77 & 69 & 94 \\
\hline & Tahora & 20 & 2 & 0 & 4 & 0 & 4 & 25 & 8 & 33 \\
\hline Red & Hamua & 20 & 45 & 11 & 62 & 33 & 100 & 9 & 18 & 72 \\
\hline \multirow[t]{2}{*}{ Clover } & Turoa & 20 & 41 & 7 & 47 & 4 & 56 & 5 & 5 & 52 \\
\hline & Pawera & 20 & 46 & 23 & 65 & 12 & 64 & 5 & 13 & 66 \\
\hline Lotus & Maku & 20 & 55 & 18 & 23 & 30 & 12 & 17 & 22 & 55 \\
\hline Sub & Mt Barker & 15 & 1 & 0 & 2 & 0 & 1 & 100 & 33 & 50 \\
\hline \multirow[t]{2}{*}{ Clover } & Tallarook & 15 & 1 & 0 & 0 & 0 & 0 & 0 & 0 & 0 \\
\hline & Woogenellup 1 & 5 & 3 & 33 & 3 & 100 & 9 & 56 & 63 & 100 \\
\hline \multirow[t]{3}{*}{ Lucerne } & Oranga & 20 & 3 & 0 & 10 & 0 & 18 & 0 & 0 & 14 \\
\hline & Wairau & 20 & 18 & 0 & 25 & 0 & 20 & 0 & 0 & 35 \\
\hline & Rere & 20 & 25 & 0 & 12 & 0 & 3 & 0 & 0 & 38 \\
\hline
\end{tabular}

Data are for official tests only and do not include retests

$\mathrm{cm}^{-2}$ for 5 minutes. 60-grit abrasive paper was used for clovers, and 100-grit abrasive paper for lucerne. Up to 5 seedlots of each cultivar were tested in a randomised complete block design which included 4 replicates of 100 seeds for each seedlot.

Normal seedlings (ISTA 1985) were counted and removed regularly during the experiment which lasted a maximum of 35 days. Final germination percentage and the number of days taken to reach $75 \%$ germination (germination rate) were determined, the latter being calculated from the viable seed portion only from within each seediot.

A germination summary for the cultivars of the 5 herbage legume species was obtained from Official Seed Testing Station records for 1983-1985.

\section{RESULTS}

Percentage germination

Of the 13 cultivars tested during 1983-85, germination was consistently greatest for Huia and Pitau white clover, an average $70 \%$ of seedlots having a germination of $90 \%$ or greater and $95 \%$ of seedlots having a germination of $80 \%$ or greater (Table 1 ). Most red clover, lotus, subterranean clover and lucerne seedlots contained high levels of hard seed, so that no seedlots or Oranga, Rere and Wairau lucerne or Tallarook subterranean clover, and less than $25 \%$ of seedlots of Hamua, Pawera and Turoa red clover, Tahora white clover and Maku lotus had a germination of $90 \%$ or greater (Table 1). However, all the red clover cultivars, Maku lotus and Mt Barker and Woogenellup subterranean clover had a 3 year average of $50 \%$ or more of seedlots with a germination of more than $80 \%$. No Kopu white clover seedlots were available for testing in these years.

The germination of the white clover, red clover and lucerne cultivars did not differ significantly within the range of germination temperatures (Table 2). The germination of Woogenellup subterranean clover was reduced at $5^{\circ} \mathrm{C}$, and that of $\mathrm{Mt}$ Barker subterranean clover reduced at $20^{\circ} \mathrm{C}$. The germination of Maku lotus was significantly reduced at $5^{\circ} \mathrm{C}$ and $5 / 10^{\circ} \mathrm{C}$.

\section{Germination rate}

Germination rate for all species slowed as temperatures moved away from the optimum (Table 3). At temperatures between 5 and $15^{\circ} \mathrm{C}$, there were no significant differences in the germination rate of white clover, lucerne and Mt Barker and 
Table 2: Final percentage germination of 14 herbage legume cultivars.

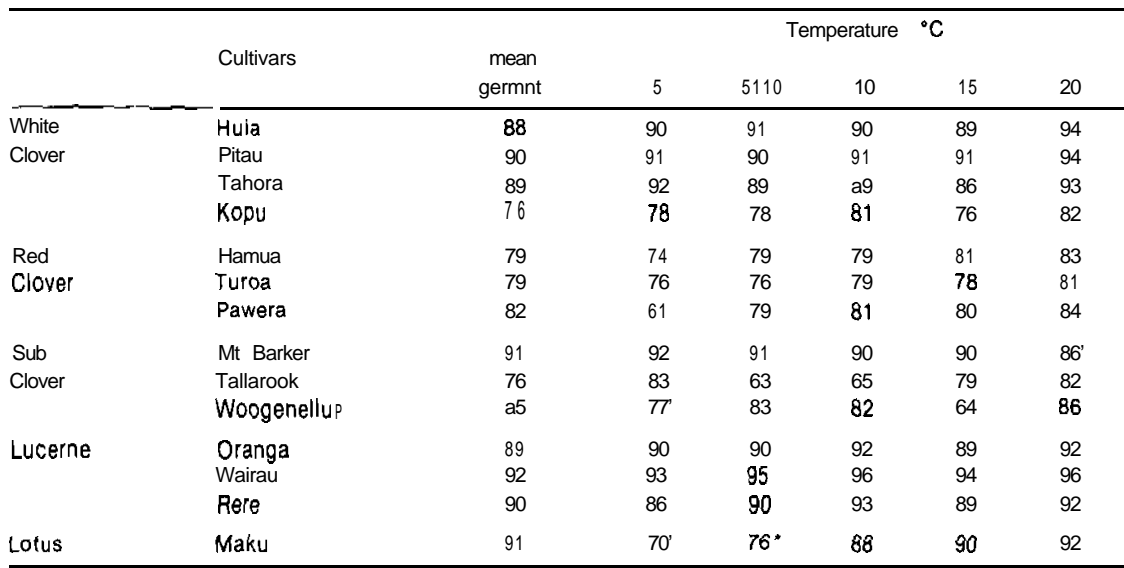

* Value significantly lower than the mean $(\mathrm{P}<0.05)$

$\uparrow$ At temperature shown in Table 1

Table 3: Germination rates of herbage legume cultivars, expressed as the number of days to $75 \%$ germiantion of viable seed.

\begin{tabular}{|c|c|c|c|c|c|c|}
\hline & & & & Tempera & ${ }^{\circ} \mathrm{C}$ & \\
\hline & Cultivars & 5 & 5110 & 10 & 15 & 20 \\
\hline White Clover & Huia & $9.2 a^{*}$ & $8.7 a b$ & $4.2 \mathrm{a}$ & $3.0 \mathrm{a}$ & $2.2 a b$ \\
\hline & $\begin{array}{l}\text { Pitau } \\
\text { Tahora }\end{array}$ & $\begin{array}{l}8.2 \mathrm{a} \\
8.2 \mathrm{a}\end{array}$ & $\begin{array}{l}7.2 a b \\
8.2 a b\end{array}$ & $\begin{array}{l}4.0 a \\
4.2 a\end{array}$ & $\begin{array}{l}3.0 \mathrm{a} \\
3.0 \mathrm{a}\end{array}$ & $\begin{array}{l}2.2 \mathrm{ab} \\
2.08\end{array}$ \\
\hline & Kopu & $8.9 a$ & $8.5 \mathrm{ab}$ & $4.0 a$ & $3.0 \mathrm{a}$ & $2.0 \mathrm{a}$ \\
\hline Red Clover & Hamua & $13.3 \mathrm{~b}$ & $10.0 \mathrm{bc}$ & $6.2 \mathrm{~b}$ & $4.6 \mathrm{~b}$ & $3.7 \mathrm{~b}$ \\
\hline & Turoa & $13.6 \mathrm{~b}$ & $9.66 \mathrm{bc}$ & $6.3 \mathrm{~b}$ & $4.4 b$ & $2.7 b$ \\
\hline & Pawera & $14.9 \mathrm{bc}$ & $10.3 \mathrm{bc}$ & $6.5 b$ & $5.4 \mathrm{~b}$ & $3.3 \mathrm{bc}$ \\
\hline Sub Clover & Mt Barker & $7.3 \mathrm{a}$ & $6.9 a$ & $4.3 a$ & $3.0 \mathrm{a}$ & $5.0 \mathrm{~d}$ \\
\hline & Tallarook & $8.3 a$ & $7.9 \mathrm{a}$ & $4.6 \mathrm{a}$ & $3.3 a$ & $4.2 \mathrm{~cd}$ \\
\hline & Woogenellup & $20.6 \mathrm{c}$ & $12.1 \mathrm{c}$ & $6.7 \mathrm{~b}$ & $5.2 b$ & $4.4 \mathrm{~cd}$ \\
\hline Lucerne & oranga & $10.0 \mathrm{a}$ & $6.0 \mathrm{a}$ & $4.0 \mathrm{a}$ & $2.7 \mathrm{a}$ & $2.0 \mathrm{a}$ \\
\hline & Wairau & $10.2 \mathrm{a}$ & $6.0 \mathrm{a}$ & $4.0 \mathrm{a}$ & $3.0 \mathrm{a}$ & $2.0 \mathrm{a}$ \\
\hline & Rere & $11.0 \mathrm{a}$ & $6.9 a b$ & $4.0 \mathrm{a}$ & $3.0 \mathrm{a}$ & $2.0 \mathrm{a}$ \\
\hline Lotus & Maku & $\cdot t$ & & $17.7 \mathrm{c}$ & $10.4 \mathrm{c}$ & $5.9 d$ \\
\hline
\end{tabular}

* Within columns, values followed by different letters are significantly different at

$p<0.05$.

† Failed to reach $75 \%$ germination of viable seed at this temperature.

Tallarook subterranean clover. However at $20^{\circ} \mathrm{C}$, the subterranean clover germination rate was slower than that of white and red clover and lucerne. The germination rate of red clover was significantly slower than that of the other clovers and lucerne at all temperatures except $20^{\circ} \mathrm{C}$. At $5^{\circ} \mathrm{C}$ and $5 / 10^{\circ} \mathrm{C}$, Maku lotus seedlots failed to reach $75 \%$ germination within the time frame of the experiments, and took between 7-13 days longer than the other species to reach $75 \%$ germination at $15 "$ and $10^{\circ} \mathrm{C}$ respectively.

Germination rate did not differ between cultivars of white clover, red clover or lucerne, but there were significant differences between the subterranean clover cultivars; the germination rate of cv. Woogenellup was slower than that of Mt Barker and Tallarook at temperatures below $20^{\circ} \mathrm{C}$. This difference increased as temperature decreased, particularly at $5 / 10^{\circ} \mathrm{C}$ and $5^{\circ} \mathrm{C}$ (Figure 1). At $5^{\circ} \mathrm{C}$, germination rate also 


\section{$\%$ GERMINATION}

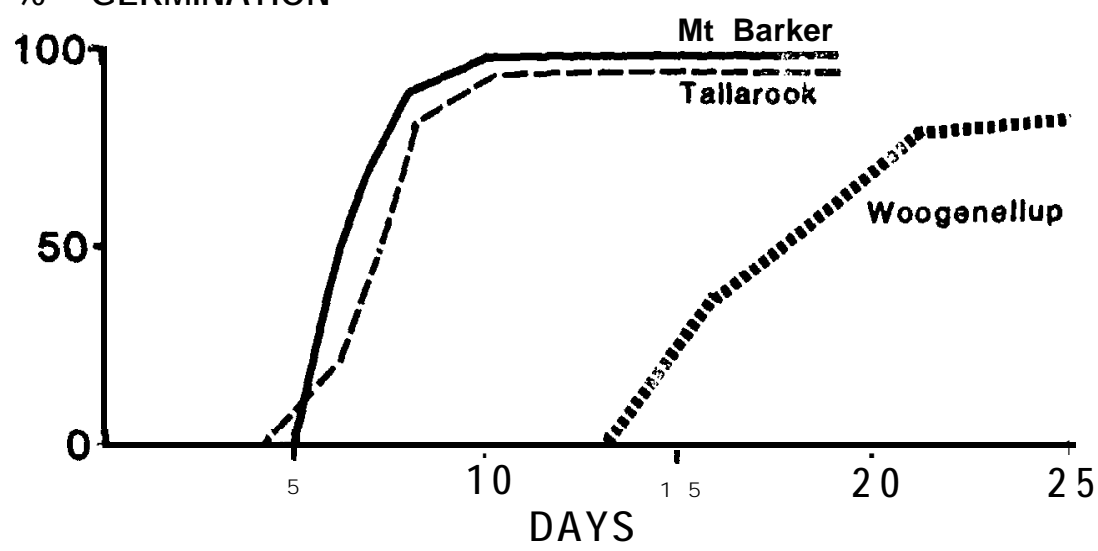

Figure 1: Germination rate of three subterranean clover cultivars at $5^{\circ} \mathrm{C}$.

differed between individual seedlots of Woogenellup subterranean clover (Figure 1), Huia and Tahora white clover and Pawera and Turoa red clover.

Days to the onset of germination increased as temperatures decreased, e.g. 1 day at $20^{\circ} \mathrm{C}, 3$ days at $10^{\circ} \mathrm{C}, 8$ days at $5^{\circ} \mathrm{C}$, but did not differ significantly between the clovers and lucerne. However, for Maku lotus, days to the start of germination were 4 at $20^{\circ} \mathrm{C}, 8$ at $10^{\circ} \mathrm{C}$ and around 50 at $5^{\circ} \mathrm{C}$. The germination response of Maku lotus at low temperatures will be discussed further in a later paper.

\section{DISCUSSION}

Herbage legumes germinated more rapidly than herbage grasses at all temperatures. For example at $5 / 10^{\circ} \mathrm{C}$, white clover took around 8 days to reach $75 \%$ germination compared with 13 days for perennial ryegrass and 26 days for cocksfoot and prairie grass (Charlton et al. 1986). While rate of germination in herbage legumes is temperature dependent, temperature within the range $520^{\circ} \mathrm{C}$ did not affect the germination of white and red clover or lucerne. However the germination of subterranean clover cv. Mt Barker was depressed at $20^{\circ} \mathrm{C}$, while that of $\mathrm{cv}$. Woogenellup was depressed at $5^{\circ} \mathrm{C}$. Previous results for temperature/germination interactions for these cultivars are conflicting. Young et al. (1970) considered that cv. Woogenellup was temperture neutral, while the germination of cv. Mt Barker was depressed at low temperatures. Evans et al. (1976) reported that emergence was consistently best for cv. Mt Barker, and significantly better than cv. Woogenellup as soil temperature decreased. Our results support the latter authors, as the germination rate for $\mathrm{cv}$. Woogenellup fell significantly compared with that of $\mathrm{cv}$. Mt Barker as temperatures decreased.

In New Zealand, recommendations for clover and lotus are for autumn sowing in North Island summer dry hill country and east coast country, spring sowing on South Island hill and high country and North Island summer wet hill country, and either autumn or spring for summer wet finishing country and North Island dairying country (see Burgess \& Brock 1985). Spring sowings of lucerne are more successful than summer and autumn sowings (Wynn-Williams 1982), while the annual, subterranean clover, should be sown in early autumn (White 1973). New Zealand autumn average $0.1 \mathrm{~m}$ soil temperatures range from $12^{\circ} \mathrm{C}$ to $17^{\circ} \mathrm{C}$ in March, $8^{\prime \prime}$ to $14^{\circ} \mathrm{C}$ in April and $4^{\circ}$ to $11^{\circ} \mathrm{C}$ in May, while in spring they range from $6^{\prime \prime}$ to $10^{\circ} \mathrm{C}$ in September, $8^{\circ}$ to $13^{\circ} \mathrm{C}$ in 
October and $11^{\prime \prime}$ to $15^{\circ} \mathrm{C}$ in November, depending upon the location. The germination data recorded in this experiment suggest therefore that the only constraint for autumn sowing of herbage legumes is to make sure that Maku lotus and Woogenellup subterranean clover are sown in March to ensure good germination; other species should germinate under the conditions experienced in late autumn or early spring. Within Maku lotus, selection for more rapid germination at low temperatures have been successfully made in the laboratory (D.J. Scott pers. comm.).

However, germination at a certain temperature in the laboratory does not always equate with establishment in the field, and there are a number of other aspects to consider. In hill country where the predominant method for the introduction of pasture species is by oversowing, soil surface temperatures are likely to be up to $5^{\circ} \mathrm{C}$ lower than $0.1 \mathrm{~m}$ soil temperatures for at least part of the germination period (Charlton et al. 1986). There may also be temperature differences between different aspect of any site. Differences in legume seedling establishment, because of site type, could be related directly to temperature variation (Charlton 1977). Musgrave (1977) demonstrated that for both lucerne and white clover sowings on widely differing sites, maximum establishment occurred when the mean $0.1 \mathrm{~m}$ seed bed temperature was in the range $3-7^{\circ} \mathrm{C}$, and that when soil temperatures were above or below this range, establishment was substantially reduced. He suggested that the poor establishment at low temperatures was due to slow germination of seed, since the germination rate of lucerne is very temperature dependent over the range $0.5^{\circ} \mathrm{C}$. At higher temperatures, establishment failure was ascribed to rapidly declining soil moisture levels (Smith \& Stiefel 1978).

Musgrave (1982) considered that only when winter temperatures fell substantially below $5^{\circ} \mathrm{C}$, e.g. in the high country or on shady aspects in the hill country, would low temperatures become a major factor limiting establishment of lucerne. While the germination of most subterranean clover cultivars at low temperatures is usually high Evans et al. (1976) found that seedbed temperatures below $10^{\circ} \mathrm{C}$ allowed only limited emergence. For lotus, poor low temperature germination and growth can result in slow seedling establishment from autumn sowings (Charlton 1977). However, red and white clovers had a satisfactory germination rate at low temperatures in hill country during winter (Charlton 1977).

McWilliam et al. (1970) questioned whether germination rate was the most important factor in the establishment of herbage legumes, and suggested that seedling vigour, involving the rate of extension of both the root and shoot, was of equal or greater importance. However, germination rate and seedling vigour are often highly correlated.

Data recorded for 1983-1985 show that the germination of herbage legumes is complicated by the presence of hard seed (Scott \& Hampton 1985). While New Zealand white clover seedlots rarely have a hard seed content of greater than $10 \%$, data reported by Scott and Hampton (1985) for officially tested seedlots from the 1984 season showed that $25 \%$ of red clover, $29 \%$ of lotus and $91 \%$ of lucerne seedlots had more than $10 \%$ hard seed. However, a high hard seed content in a seedlot does not mean the seedlot is of low value. The hard seed content can be reduced by scarification, although care must always be taken to ensure that the physical stress applied is not so severe that it damages the seed and thus reduces germination by producing abnormal seedlings. Alternatively, the seedlot can be used for oversowing in autumn, where low winter temperatures followed by warm spring days and cool nights should induce most of the hard seed in the seedlot to germinate.

The ability of herbage species to establish in competitive, multispecies swards is related to genotypic characters such as seed size and quality of seed reserves 
(Charlton et al. 1986). Variation exists within and between herbage legume species in relation to the germination rate and vigour of early seedling development, and selection to improve these attributes, particularly under low temperatures, may well be justified (McWilliam et al. 1970, Charlton 1977).

\section{CONCLUSIONS}

1. Herbage legumes germinate more rapidly than grasses at all temperatures. Therefore, with the exception of Maku lotus and Woogenellup subterranean clover, the time of sowing for seed mixtures will depend on the grass component.

2. Maku lotus germinates poorly at $5^{\circ} \mathrm{C}$ and $5 / 10^{\circ} \mathrm{C}$, and Woogenellup subterranean clover at $5^{\circ} \mathrm{C}$. Both must be sown when soil temperatures will allow germination (i.e. March for autumn sowings of both species, and September/October for spring sowings of Maku).

3. Red and white clover and lucerne are less temperature dependent and can be sown in late autumn (clover) or early spring (clover and lucerne). However, providing soil moisture is adequate, better establishment will result from sowings in early autumn (March/April) and mid spring (October).

4. A high hard seed content in a seedlot does not mean the seedlot is of low value. The hard seed can be broken by scarification; or alternatively the seedlot can be used for oversowing (not drilling) in autumn, where fluctuating temperatures during the winter and early spring will induce most of the hard seed to germinate.

Acknowledgement

We thank staff of the Official Seed Testing Station for assistance with germination analyses and J.R. Sedcole for statistical analysis of data.

\section{References}

Burgess R.E., Brock J.L. 1985. Using Herbage Cultivars. Grassland Research and Practice Series N. 3, New Zealand Grassland Association, $108 \mathrm{pp}$.

Charlton J.F.L. 1977. Establishment of pasture legumes in North Island hill country. II. Seedling establishment and plant survival. NZ Journal of Experimental Agriculture 5: 385.390.

Charlton J.F.L. 1962. Initlal trials for improvement of North Island hill country by conservation tillage Proceedings of the 1961 seminar on conservation tillage, Monsanto Ltd, Christchurch, November 1961, 27.34

Charlton J.F.L., Hampton J.G., Scott D.J. 1986. Temperature effects on germination of New Zealand herbage grasses. Proceedings NZ Grassland Association 47: 165.172.

Cullen N.A. 1971. Factors influencing establishment of oversown grasses and clovers on unploughable hill country. Intermay Agricultural Research Centre Research Report No. 1, Ministry of Agriculture and Fisheries.

Evans R.A., Kay B.L.. Young J.A. 1976. Influence of date of planting on emergence of cultivars of Trifolium hirtum All. and T. subterraneum L. Journal of Range Management 29, 333-337.

International Seed Testing Association (ISTA) 1965. International Rules for Seed Testing. Seed Science and Technology 13: 300.513 .

Lancashire J.A. 1985. Some factors affecting the rate of adoption of new herbage cultivars. In: Burgess R.E., Brock J.L. (Eds). Using Herbage Cultivars. Grassland Research and Practice Series No. 3, New Zealand Grassland Association.

McWilliam J.R., Clements R.J., Dowling P.M. 1970. Some factors influencing th germination and early seedling development of pasture plants. Australian Journal of Agricultural Research 21: 19-32.

Musgrave D.J. 1977. Effects of time of sowing on the establishment of Oversown legumes. Proceedings NZ Grassland Association 38: 160.166

Musgrave D.J. 1962. Lucerne establishment $\rightarrow$ oversowing and overdrilling. In: Wynn-Williams R.B. (Ed.), Lucerne for the 80s, 21-31, Agronomy Society of New Zealand Special Publication No. 1.

Scott D.J., Hampton J.G. 1985. Aspects of seed quality. in: Hare M.D., Brock J.L. (Eds). Producing Herbage Seeds. Grassland Research and Practice Series, N. 2, New Zealand Grassland Association. 
Smith R.G.. Stiefel W. 1978. Pasture and lucerne research on sand country. Proceedings NZ Grass/ano Association 39: 61.69

Suckling F.E.T. 1959. The effects of topdressing and oversowing hill pastures. NZ Journal of Agricultural Research 2: 153-164.

White J.G.H. 1973. Pasture establishment. In: Langer R.H.M. (Ed.). Pastures and Pasture Plants. 129-157. A.H. and A.W. Reed, Wellington

Wynn-Williams R.B. 1962. Lucerne establishment - conventional. In: Wynn-Williams R.D. (Ed.). Lucerne for the $80 \mathrm{~s}, 11-19$, Agronomy Society of New Zealand Special Publication No. 1.

Young J.A., Kay B.L., Evans R.A. 1970. Germination of cultivars of Trifolium subterraneum L. Agronomy Journal 62: $638-641$ 